University of Louisville

ThinkIR: The University of Louisville's Institutional Repository

$5-2014$

\title{
Some place to be that's not on the map : Chuck Palahniuk's demarginalization of the gothic monster.
}

Morgan Blair

University of Louisville

Follow this and additional works at: https://ir.library.louisville.edu/honors

Part of the English Language and Literature Commons

\section{Recommended Citation}

Blair, Morgan, "Some place to be that's not on the map : Chuck Palahniuk's demarginalization of the gothic monster." (2014). College of Arts \& Sciences Senior Honors Theses. Paper 93.

http://doi.org/10.18297/honors/93

This Senior Honors Thesis is brought to you for free and open access by the College of Arts \& Sciences at ThinkIR: The University of Louisville's Institutional Repository. It has been accepted for inclusion in College of Arts \& Sciences Senior Honors Theses by an authorized administrator of ThinkIR: The University of Louisville's Institutional Repository. This title appears here courtesy of the author, who has retained all other copyrights. For more information, please contact thinkir@louisville.edu. 
"Some Place to be that's not on the Map": Chuck Palahniuk's Demarginalization of the Gothic Monster

By

Morgan Blair

Submitted in partial fulfillment of the requirements

for Graduation summa cum laude

and

for Graduation with Honors from the Department of English

University of Louisville

March 2014 


\section{TABLE OF CONTENTS}

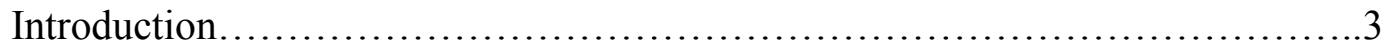

Section I: Development of Gothic Discourse........................................................

Section II: Philosophy of "The Monster" ....................................13

Section III: Demarginalization in Palahniuk's Fiction: What Scholars are (not) Saying ....................................................................

Section IV: "Some Place to be that's not on the Map": Implacable Monstrosity

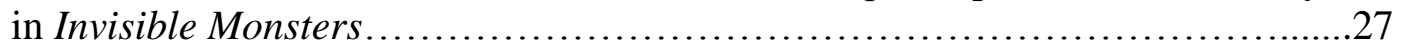

Works Cited............................................................. 35 


\section{INTRODUCTION}

In his extensive exploration of the various cultural instantiations of monstrosity, Stephen Asma dedicates a chapter, appropriately titled "Inner Monsters," to the monster of the Enlightenment era. Acquiring a psychological attention by critics, the literary monster within this framework is portrayed as a "product of human superstition that can be conquered by the light of reason" (Asma 202). Constructed for the purpose of warning against repressed desires that are viewed as negative by social or moral codes, the monster consequently adopts the status of the Other. However, undoubtedly influenced by Freud's simultaneous development of psychoanalytic theory, the modern monster is utilized in fiction not only to distance socially but also to explore these repressed characteristics. Therefore, the fictional monster accrues a similitude toward reader in order that readers might empathize with figures of simultaneous horror.

While this subversive technique appears to dismantle social categorization, it effectively reinforces this process in its dependence upon reader internalization of binary categories. Indeed, this sociological implication is afforded little scholarly attention in the shadows of the more popular psychoanalytic perspective. However, as Asma asserts, "monsters after [sin] Freud are features of the irrevocable irrationality inside the human subject and outside in nature" (202). With the addition of this attention to the external — rather than solely internal—implications of monstrosity, there necessitates a simultaneous sociological consideration. Within Gothic fiction, Samuel Beckett initiates this sociological investigation of reader and monster (subject and object) by destabilizing this oppositional relationship. Contemporary writers Bret Easton Ellis and Chuck Palahniuk adopt this deconstructive attitude in order to express monstrosity in a way that is both psychologically subversive and socially transgressive. While Ellis universalizes 
monstrosity in an effort to undermine social confinement of the Other, Palahniuk incorporates an ontological perspective based on radical flux. In a world of infinite play between signifier (subject) and signified (object), marginalization of the monster is impossible. "There is no grand narrative, no universal human nature, no objective reality, no Enlightenment truth to be captured by reason," (252).

Therefore, these writers' works embody a monstrosity derived from a functional versus definitive basis. Asma explains that "in earlier theories, from Aristotle to logical positivism, we assumed that every instances of bird or bed or monster must satisfy an abstract essential definition [...] Wittgenstein, however, noticed that most things were not connected by a common definition, but instead share overlapping similarities" (282). He further asserts that this mode of thinking about categorization has acquired the label of prototype theory. Similarly, the monstrosity that this thesis attributes to the fiction of Beckett, Ellis, and Palahniuk is conceived not as an intrinsic characteristic of the main protagonist but rather as a functional conformity to archetypal monsters that threaten binary boundaries, exacerbate unease, and compel readers. In Invisible Monsters, Palahniuk utilizes the archetypes within preceding Gothic discourse as a tool for deconstructing the confined territory in which the monster resides. In this way, his appropriation of Gothic discourse is socially transformative. 
Section I: Development of Gothic Discourse

In the introduction to a collection of essays titled Gothic and Modernism, John Paul Riquelme attributes the development of Gothic writing as a discourse of modernity primarily to two texts: Wilde's The Picture of Dorian Gray (1891) and Stoker's Dracula (1897). These works, being heavily influenced by Stevenson's The Strange Case of Dr. Jekyll and Mr. Hyde (1886), provide models for representing cultural and anthropological concerns regarding difference via literary forms that are self-cognizant in terms of structure (Riquelme 5). A particular development of early modernity that indicates this self-cognizance is structural doubling, whereby the form of a text mirrors the dual nature of character identity. Form functions on both a literal level (fulfilling its narrative purpose) and a metaphorical level (fulfilling its subversively psychological purpose). By positioning seemingly similar objects in opposition toward one another or, inversely, seemingly dissimilar objects parallel to one another, writers who employ this technique exacerbate unease in readers by exposing either the validity of their intuitive beliefs or the invalidity of their empirically-based beliefs. This psychoanalytic strategy is particularly useful in exposing social and psychological conventions, for its subversive impact on readers temporarily displaces reader from self. The result of this displacement is a destabilization of reader subjectivity and an introspective objectivity with which reader might examine self through a third-party lens, i.e. that of the morally transgressive protagonist. Furthermore, this reversal of reader position from subject (watching) to object (selfwatching) suspends ethical binaries that otherwise might limit their capacity to identify with the deviant protagonist. In this way, structural doubling complicates the expression of monstrosity in modern Gothic narrative as it transforms the monster as distinctively Other into a subjective tool for psychological exploration. 
As a result of this internalization of the monster during modernity, reader response accrues an emphasis on intellectual engagement alongside the previous high emotionalism of the Gothic. Seeking to understand that which they fear and the source of this fear, readers seek this intellectual engagement as a means of questioning, re-affirming, or denying moral values or social codes. Stephen T. Asma explains that "our ethical convictions do not spring fully grown from our heads but must be developed in the context of real and imagined challenges. In order to discover our values, we have to face trials and tribulation, and monsters help us imaginatively rehearse" (Asma 3). By this definition, there must be an Othered figure that is constituted by negative societal values with which to reaffirm or deny positive values, and anthropomorphized monstrosity remedies this predicament.

This observation reveals an essential tension that must exist for sustenance of the monster as Other within texts employing such convention — order, rationality, form, and idealism must contrast disorder, fragmentation, the marginal, and the unconscious. Furthermore, readers must accept and internalize such a binary logic in order to rehearse effectively with an Othered figure. In Aggressive Fictions: Reading the Contemporary American Novel, Kathryn Hume claims that the grotesque Other is the direct result of a disruption of balance between these polarized categories. She contends that the Grotesque "may be a hybrid of the two; it may operate by reversing the poles; it may be neither-nor; it may represent a third option in its own right. Somehow, though, it emerges in the gap between the poles" (Hume 79). This relocation of the monster into an ambiguous category of existence is typical of late modernity/early postmodernity and is an attempt to weaken even further the monster/reader dichotomy. A particularly deconstructive approach, it is comparable to feminist Elizabeth LeBlanc's predication of an ambiguous gender category, that of the "metaphorical lesbian." She explains that "the 
metaphorical lesbian recognizes those limitations [of patriarchal binary discourse] and resists them, searching until her final moments for an alternative way of speaking. That resistance in itself provides a kind of self-definition that underlines [the metaphorical lesbian's] consistent use of "otherness"" (LeBlanc 244). While these constructions of ambiguity appear to offer their marginalized figures an escape from the patriarchal system of binary logic - "the monster is that which escapes sole confinement in one of these categories"-, both Hume and LeBlanc ironically sustain the system. That is, their creations of new centers of discourse (i.e. an ambiguous category) reinforce the necessity of binary boundaries with which to define the feminine and monstrous Others. Nevertheless, the transitional attitude bordering late modernity and postmodernity contributes a complexity of expression that seeks to dissolve the hierarchical relationship between monster/reader and, consequently, form/content that later is extended by writers such as Bret Easton Ellis and, as this thesis will argue, most radically by Chuck Palahniuk.

Graham Fraser discusses the effects of this transitional attitude on form and content in early postmodernity by appealing to a late novella of Beckett, titled Ill Seen, Ill Said. The novella is representative of a style which he calls "Beckettian Gothic," being "melancholy, unstable, self-consuming and self-haunting" (Fraser 178). A work that is self-conscious of its employment of the Gothic tropes of being haunted by the Other and watching/seeing an objective Other, the text blurs "distinction between self and other, actuality and ghost" (Fraser 178). Fraser summarizes the basic situation of the work in the following way: "A disembodied, hovering eye inspects a circular, barren landscape, following the movements of an immaterial old woman as she paces between the ramshackle cabin which is her 'abode' and a 'distant tomb' at the margins of the scene" (169). He continues to discuss the self-reflexivity of the text by 
addressing the opening pages, in which the narrator hints at a shared identity between the spectral eye and the main protagonist: "'she shows herself only to her own. But she has no own. Yes yes she has one. And who has her"' (Beckett qtd. in Fraser 179). Here, Fraser explains that in creating an ambiguity of identity concerning observer (the eye) and observed (the woman), Beckett denies readers the possibility of labeling an Other figure due to this lack of subject/object distinction. Furthermore, Beckett does not distinguish whether the woman is alive or dead, existent or non-existent, body or spirit. In denying these binary distinctions, he demonstrates an indeterminacy — "everything [is] spectral, there and not there, or in flux between these two states but never conclusively achieving either,"- that, likewise, denies the reader a stable perspective by which to judge an Other figure (Fraser 172). This ontological and narrative indeterminacy is particularly significant in terms of the Gothic because it demonstrates a deconstructive attitude toward the genre. Writers such as Palahniuk hone this self-disruptive technique within Gothic discourse to initiate a self-disruptive process whereby Gothic tropes, "stripp[ed] of much of the emotional, visceral energy that typifies Gothic literature," not only deconstruct themselves but in doing so disorient readers (Fraser 170). Furthermore, this attitude establishes a precedent for expressing monstrosity as an indeterminate process that is denied physical manifestation. In the context of instability and immateriality, defining monstrosity in association with physical attributes is no longer possible. The effect that this denial has on reader implication involves a stripping away of emotionalism and, instead, a disorienting and heavily intellectual engagement with narrative.

Whereas Beckett utilizes a "hauntological" approach toward denying monstrosity a physicality and, hence, destabilizing boundaries necessary for upholding an Othered category, postmodern fiction writer Brett Easton Ellis universalizes monstrosity (Fraser 170). That is, he 
takes a critical step in the development of monster discourse by granting an apparent manifestation of monstrosity in his protagonist Patrick Bateman while simultaneously utilizing this figure to assert that Bateman's monstrosity is diffused throughout the consumerist society. Hence, he combines intellectual engagement of the topic with an emotionalism afforded by bodily manifestation of Otherness. Ellis's protagonist, whose social veneer aligns him alongside readers, is portrayed as an everyman who succumbs to "bestial urges," a submission that indicates that this potential for monstrosity "[lies] dormant in all of us, and the only difference between us and Patrick is that he has indulged them" (Heyler 130). Furthermore, like readers who identify with Ellis's protagonist, Bateman recognizes that these urges cast him into a category of difference within his society. Therefore, when he encounters various socially marginalized figures (e.g. women and homeless individuals), he perceives threat because these figures essentially function as mirrors for his own non-conforming position within society. Indeed, Bateman constantly seeks to subvert this Otherness by conforming, if not morally, then aesthetically to consumerist society_-"I change into Ralph Lauren monogrammed boxer shorts and a Fair Isle sweater and slide into polka-dot Enrico Hidolin slippers," he informs readers (Ellis 26). The significance of this aesthetic conformity is that it allows Bateman to position himself alongside readers, a position which is necessary for his reader subversion. By providing readers with a protagonist with whom they can identify on some level, Ellis effectively implicates readers in the transgressive deeds of his monstrous protagonist. A particularly effective use of this technique occurs when Bateman feeds his girlfriend a "used urinal cake covered in cheap chocolate sauce but masquerading as a tempting delicacy in a Godiva box," and recounts that she 
looks like a big black ant—a big black ant in an original Christian Lacroix—eating a urinal cake and I almost start laughing [ . . . Even though I marveled at her eating the thing, [sin] I'm reminded that no matter how satisfying it was to see Evelyn eating something that I, and countless others, had pissed on, in the end the displeasure it caused her was at my expense-it's an anticlimax, a futile excuse to put up with her for three hours. (Ellis 337)

In this instance, readers are entertained by notably one of the least transgressive acts of the main protagonists. Several factors contribute to their identification with the deviant protagonist rather than his unknowing, "normal" girlfriend—dramatic irony and Bateman's matter-of-fact narration are two of these. A more subtle element that situates readers within this scenario, however, is the coded consumerist language—Godiva, Christian Lacroix, etc.

Another significant element, and perhaps the most distinctive contribution of Ellis toward continuation of the Gothic within postmodernity, is the parodic mode through which he reveals this ironic diffusion of monstrosity within consumerist culture. This employment of parody functions as a continuation of the modernist precedent of structural doubling. Ellis radicalizes the doubling effect in American Psycho as his protagonist, rather amusingly, is repeatedly mistaken to be other persons. Furthermore, in a fulfillment of Ellis's parodic attitude, Bateman responds as if he actually possessed these mistaken identities. Throughout the novel, Bateman also confesses to his monstrous deeds, yet his societal peers humorously dismiss these confessions. Similarly, he explicitly recounts these deeds to readers- 'I'm coming back from Central Park where, near the children's zoo, close to the spot I murdered the McCaffrey boy, I fed portions of Ursula's brain to passing dogs" (Ellis 384) While the content of this direct address is disturbing, readers dismiss this confession as merely characteristic of Bateman, 
someone who is both Other and same. Bateman's peers, however, dismiss his confession because they cannot conceive of a monster that exists within their social circle. Heyler asserts that "the failure of others to recognize [Bateman] for what he is, despite his frequent confessions, assists him in creating his own version of reality, an apocalyptic reality that validates his priorities and perspective, one that questions the generally accepted version of "normal"' (141). By creating a character that does not fulfill public expectation of difference based upon appearance and other socially coded values, Ellis also utilizes parody as a means of undermining such categorization. A monster that navigates between boundaries of excess and lack is unsuspected by a society encoded with such binary logic.

Palahniuk exercises a similar technique in Invisible Monsters, although his tone is more direct and bitingly satiric. Palahniuk's protagonist, Shannon McFarland, openly expresses her frustration with the situation exemplified by Bateman's confessions, i.e. a societal assumption that the monster is distant, Other-than, and physically abhorrent versus within society, self-same, and potentially hidden beneath a conforming appearance: "They'd like me to sit here in the dark and pretend it's the outside world we're hiding from. It's some hateful stranger that's going to come get us in the night. It's some alien fatal sex disease. They'd like to think it's some bigoted homophobe they're terrified of" (Palahniuk 150-1). Shannon is referring literally to her parents' reaction toward their homosexual son, whom they assume to have AIDS due to his sexuality, as well as their imagined hate-criminals who harass them prominently via telephone threats. Similar to the humorous irony of Bateman's situation, in which readers know the validity of his bestial confessions, readers of Invisible Monsters are able to acknowledge (less humorously) the irony of Shannon's words because of her own physical deformity and transgressive deeds of which her parents are unaware. Readers also discover later that the harassing telephone calls are 
from Shannon, herself, whom her parents believe to be away at a photo shoot in Cancún, Mexico. This discovery extends an already satiric situation into a revelation that the perceived external threat lies, ironically, within a familiar context.

The extent of Shannon's parents' judgmental as well as hypocritical attitude toward that which they do not understand is revealed on one occasion when a physically deformed and unintelligible Shannon calls her father. Unable to comprehend Shannon's jumbled language, her father hands the receiver to Shannon's mother, who answers: “'Hello? [...] There's room in God's heart for all His children. Gay, lesbian, bisexual, and transgendered"' (Palahniuk 142). Next, Shannon overhears her father in the background: “'you still talking to those lunatics?" (142). Eventually, the conversation that, really, is one-sided, develops into Mr. McFarland roaring defensively, "You, you're the one who should be dead...You killed my son, you goddamned perverts"' (Palahniuk 142). In this instance, Palahniuk utilizes an irony that combines both a familiar situation with a more direct commentary, as revealed by Shannon's description of her own social marginalization. The effect of this repetition of indirect and direct social commentary is a self-cognizance that allows Palahniuk subtly to undermine the categorization of difference while developing an awareness in readers of their own recognition of this issue (the testimony to this awareness being their sympathy toward Shannon and their familiarity with the reaction of the McFarland parents). One of several subversive techniques honed by Palahniuk in order to dissolve reader subjectivity, his satiric mode of expressing the hypocrisy (ergo, instability) of the gazing subject toward an Othered object allows him effectively to dissolve this oppressive relationship. Furthermore, it is indicative of the transitional attitude toward a figure that ideally is Other-than yet realistically defies this concise classification. 


\section{Section II: Philosophy of "The Monster"}

Categorization of a monster figure in Gothic discourse relies upon two clusters of opposing values, one concerning rationality and form and the other concerning irrationality and chaos. Furthermore, as mentioned previously, Hume asserts the Grotesque arises within a third space that is "somehow enterable by both, in which the values transform each other, their interaction or merging causing the reader discomfort" (85). Pertaining this system is a dichotomous as well as oppressive mode of thought which has its origins in the metaphysical dualism introduced by Plato during the $5^{\text {th }}$ Century BC. A significant influence on Plato's dualism is revealed by Aristotle in Metaphysics to be a Heraclitean-influenced philosopher from Plato's youth named Cratylus, whose influence James Jordan describes in the following way: Cratylus [sin] taught [Plato] that the whole existence is in such radical flux that everything escapes our attempts to comprehend it. Nothing remains the same or stands still long enough for us to say anything even approximately accurate about it. Heraclitus had declared that you cannot step into the same river twice. Cratylus insisted that you cannot step into it even once, so incessantly is everything changing in every respect. (Jordan 78-9)

Jordan further asserts that Plato's theory of forms arises in response to this extreme flux doctrine of Cratylus, a doctrine that denies the existence of "distinctive patterns or forms" and, hence, "no persons or things with definite characteristics in which they could resemble one another.

General definitions as to what all virtuous persons and good things have in common would be out of the question" (Jordan 79). Recognizing the oppositional nature of Cratylus's flux doctrine and Plato's idealism, one might assert a similar opposition between the literatures influenced by 
each theory. Indeed, as noted in Section I of this thesis, a culture that internalizes a logic based on Platonic idealism produces monster figures that contrast dramatically with those of a culture influenced by flux. Furthermore, the monstrosity introduced by Palahniuk in Invisible Monsters has its roots in a radical strand of flux. Compared with his postmodern contemporaries, he most effectively dissolves boundaries necessary for upholding monstrosity as Other by negating, like Cratylus, the possibility of general definitions concerning existence and identity. An understanding of how Plato's idealism contributes to an oppressive system of binary logic by asserting these definitions provides insight into the modern monster as an entity employing this logic. Additionally, this prior understanding of idealism allows for a thorough comprehension of how deconstruction arises as a significant tool for postmodern Gothic writers, specifically for Palahniuk.

In Phaedo, Plato establishes his theory of forms, which distinguishes between a world of forms and one of instantiations of those forms. He explains that the forms are incorporeal, static entities - absolute unity, absolute beauty, etc. - and, as such, represent the highest form of order, the underlying principle of order for the universe. Hence, forms, insomuch as they "possess full reality," are the ideal states to which all sensible things strive to "measure up, or resemble, or participate in" (Jordan 88). Plato exemplifies this imitative relationship in Phaedo by addressing equality. Paraphrasing Plato's example, Jordan explains that “two sticks or stones, however equal they may at first seem in size or in weight, will be found to fall short of perfect equality. Perfect equality, like perfect straightness or squareness or circularity, never shows up in our experience. The best we can expect is an approximation that is tolerably close" (87). This theory is influenced by a teleological worldview, asserting that the purpose of all sensible things is "to be as perfect an instance of that kind of thing as it possibly can be" (Jordan 91). This 
teleological relationship between forms and their instantiations depends upon a hierarchy of being, and this association of being with perfection initiates a tradition of binary thinking that manifests itself in monster discourse. Form/thing, reality/appearance, unity/plurality, perfection/imperfection, immortal/mortal, eternal/temporal, divine/human — these oppositions assert an oppressive system of categorization not only by establishing a logic of superiority versus inferiority of being, but also by unconsciously creating a third, ambiguous territory. Perhaps this is the space to which Kathryn Hume refers in her definition of the Grotesque - that which is a hybrid of the polarized categories or, perhaps more horrific, outside of both categories and inconceivable by the terms of established discourse.

Jacques Derrida addresses the oppressive nature of Plato's dualism, a system that he claims to be fundamental within the logocentric discourse of Western society. Furthermore, he asserts this oppressive nature in his definition of metaphysics:

[Metaphysics denotes] the enterprise of returning 'strategically,' 'ideally,' to an origin or to a priority thought to be simple, intact, normal, pure, standard, self-identical, in order then to think in terms of derivation, complication, deterioration, accident, etc. All metaphysicians, from Plato to Rousseau, Descartes to Husserl, have proceeded in this way, conceiving good to be before evil, the positive before the negative, the pure before the impure, the simple before the complex, the essential before the accidental, the imitated before the imitation, etc. And this is not just one metaphysical gesture among others, it is the metaphysical exigency, that which has been the most constant, most profound and most potent. (Reynolds)

According to Derrida, Western binary thought favors the simple, the good, and the imitated 
at the expense of marginalized categories of the complex, the impure, and the inauthentic. It is self-defeating merely to subvert these categories as a means of re-establishing power to the subordinate category, Derrida argues, for the superior category only would fill the position of inferiority, effectively reinstating the oppressive relationship. Rather, Derrida expresses the need for a displacement of the entire system of binary thought by dissolving such a system. He coins the term deconstruction for this new perspective that denies absolute, definitive categories of existence and disrupts the concept of observer being entirely objective to object being observed (in this case, reader and text).

Given the prominence of binary thought within Western discourse, deconstructionist influence on social thought, particularly pertaining to minority populations, may come as no surprise. For the purposes of this thesis, and given the unavoidable emphasis on gender, femininity, and sexuality within the Gothic genre, it is beneficial to examine the implications that Derrida's attitude toward binary thought has held for feminist criticism. An understanding of these implications within French feminism, in particular, is beneficial in considering Chuck Palahniuk's transformation of the monstrosity in Invisible Monsters, a work in which dissolution of the oppressive binary system that formerly incarcerated the monster is of primary focus. Derrida's influence on French feminism is effectively conveyed in Hélène Cixous's manifesto, "The Laugh of the Medusa." Cixous appropriates, within the context of phallic privilege, Derrida's concept of a linguistic social structure dependent upon binary opposition. She specifies woman as the negative within a binary language build on male versus female, and therefore conceives of woman as Other, being defined in terms of what the dominant male lacks. A particularly Derridean assertion in Cixous's introduction — and an indication of Chuck 
Palahniuk's attitude toward the binary construction of the modern Gothic monster-is her description of woman's relationship toward history:

The future must no longer be determined by the past. I do not deny that the effects of the past are still with us. But I refuse to strengthen them by repeating them, to confer upon them an irremovability the equivalent of destiny, to confuse the biological and the cultural. Anticipation is imperative. (Cixous 875)

Here, Cixous is referring to woman's historical position within Western society, her emphasis being the need for a new writing uninfluenced by a history fraught with phallogocentric discourse. Although concerning woman in the case of Cixous, this attitude mirrors that of Palahniuk toward the position of the Gothic monster within literary tradition. Palahniuk similarly attempts not to sever the ties between modern Gothicism and postmodern Gothic fiction but rather to re-think the monster within a context free of binary dependence. Therefore, he does not abandon Gothic tropes entirely, but rather he incorporates and transforms these elements in a radically new way.

Additionally, Cixous's examination of the relationship between observer and Other reflects an attitude that Palahniuk adopts in his subversive positioning of reader and protagonist Cixous is reflecting upon the fear associated with the subordinate entity within a binary relationship and the primitive acceptance of this reaction by society. Describing the marginalized figure in Western society, she asserts:

As soon as they begin to speak, at the same time as they're taught their name, they can be taught that their territory is black [...] your continent is dark. Dark is dangerous. You can't see anything in the dark, you're afraid. Don't move, you might fall. Most of all, 
don't go into the forest. And so we have internalized this horror of the dark. (Cixous 877-8)

Palahniuk's characters actively seek to subvert this fear of the dark into a desire for the unknown territory, and by implicating readers in the emotions/actions of his protagonist, Palahniuk effectively subverts this fear for readers, as well. This subversion allows Palahniuk to dissolve the binary system of thought in such a way that, by aligning reader with monster, results in an internal dissolution of morals, values, and judgments based upon this oppositional system. As Cixous claims for the woman within such a system, the process of dissolution "is already upon us - in the United States, for example, where millions of night crawlers are in the process of undermining the family and disintegrating the whole of American sociality" (883). Furthermore, as works such as Ellis's American Psycho and Palahniuk's Invisible Monsters exemplify, a similar deconstructive effort exists within contemporary constructions of literary monstrosity. 
Section III: Demarginalization in Palahniuk’s Fiction: What Scholars are (not) Saying

Alongside other French feminists, Rosi Braidotti asserts woman's confinement to the territory labeled irrational in terms of patriarchal thought. Therefore, she demands a redefinition of the relationship between human subjectivity and difference, specifically constructions of Otherness. Furthermore, this redefinition of relationship demands a redefinition of discourse. She asserts that "academics will have to agree that thinking adequately about our historical condition implies the transcendence of disciplinary boundaries and intellectual categories" (77). Within a fictional context, writer Chuck Palahniuk adopts this position while reconfiguring the Gothic monster. He most effectively liberates the monster from a category of Otherness within his 1999 novel Invisible Monsters, a work in which he radically transforms reader/monster relationship in order to achieve this effect. Furthermore, he combines elements of the Gothic genre with those of a deconstructionist influence, effectively "transcending [the] disciplinary and intellectual categories" specified by Braidotti (77).

However, despite Palahniuk's sociological attention to the fictional monster, there is minimal scholarly attention that specifically addresses this focus. Furthermore, there is no current discussion of his pre-Socratic influence, particularly that of flux, which allows him to dislocate monstrosity as an Othered category. While few scholars do, indeed, address separately his employment of the Gothic genre and his deconstructionist attitude within Invisible Monsters, this criticism does not directly explore the relationship of these two approaches within the context of social marginalization.

In his article “On Mutilation: The Sublime Body of Chuck Palahniuk’s Fiction,” Andrew Slade hints at an intersection between Palahniuk's deconstructionist attitude and the sociological motivation that underlies his portrayal of the sublime. Associating Palahniuk's fiction with the 
theme of survival, he asserts that Palahniuk's protagonists must struggle to overcome the oppressiveness of American culture, which is "sick" (Slade 63). Furthermore, he identifies the source of such oppression to be consumerist culture and the power of escape to exist in bodily mutilation:

In a world where the difference between the fake and the authentic can barely be discerned or sustained, only the most violent negations of appearances, mutilations, can give us something we can believe in, a new authenticity. The sublime figure of the mutilated body redeems the authenticity of the world. (72)

Although Slade's assertion that self-mutilation provides authenticity and escape from societal oppression seems to be a plausible explanation for Palahniuk's liberation of the Other, it merely re-establishes a system of oppressive binaries. If the self-mutilated body becomes the new center for monster discourse, then that which lies without the center, i.e. the non-mutilated and the beautiful, merely takes the place of the Other. Furthermore, Palahniuk's protagonist expresses directly the insufficiency of her self-mutilation for providing such escape from discourse. Not only did "the little paper tiger attempts to reject looking good [sin] only end up reinforcing it," but also does her more radical attempt prove insufficient. "The truth is, being ugly isn't the thrill you'd think," she admits (287). However, recognizing by the end of the novel her ability to recreate herself endlessly, she expresses an optimism afforded by such infinite play_-it can be an opportunity for something better than I ever imagined" (288). Therefore, Palahniuk ultimately celebrates the infinite play afforded within a fictional context based on impermanence of identity, as indicated by his protagonist's final words. This optimistic tone, however, is commonly ignored by Palahniuk's critics, as indicated by Slade among others. 
Andrew Ng similarly addresses bodily mutilation as a means of escape from commodification by the culture industry, yet his tone is more optimistic than that of Slade. He explains that "merely material, the subject [within a capitalist system] is [sin] categorized in terms of how he 'matters' to the culture industry that prescribes value to him," ( $\mathrm{Ng} 25)$. Therefore, acknowledging this association between body ("a socio-ideological construction") and experience, Palahniuk's characters seek gender reconfiguration and self-mutilation as a means of destroying their culture-prescribed value/experience and "relocate[ing] experience back within themselves" ( $\mathrm{Ng} 26)$. Self-destruction, then, becomes an essential means of achieving authenticity in a postmodern, capitalist society. Similar to that of Andrew Slade, Ng's attribution of monstrosity to characters that transform the body in order to escape capitalist discourse is centered on a claim of becoming/turning monster, and achieving authenticity.

While Palahniuk, indeed, utilizes flux as a necessary feature of identity formation for protagonist and reader alike, he does not assert flux as a means of achieving some state deemed monstrous. He might, like $\mathrm{Ng}$ suggests, seek physical transformation as a medium of flux in the novel due to its Foucaultian association with a locus of experience, hence its connotation as a dynamic process through which a sense of self constantly may be destroyed, renewed, or reshaped. However, Palahniuk denies monstrosity and authenticity alike as states of being and, hence, possibilities both literarily and socially. Ng's assertion of this state of being monstrous reinforces the dichotomous thinking that Palahniuk attacks, for it assumes an idealism and a hierarchy of existence. Ng's strategy for discerning monstrosity as a reclamation of the body, hence a reclamation of experience, is self-contradictory in its attribution of becoming alongside being, for it employs dualism (not-being/being) while claiming to promote pluralism. This pluralism is a necessary tool for Palahniuk's undermining of monster-as-Other, and it similarly is 
pertinent to the situation of woman as Other. $\mathrm{Ng}$ even draws this parallel himself, quoting Braidotti:

At times of fast-changing social and cultural conditions, the mutant, hybrid, monstrous others accelerate to an almost vertiginous degree the destabilization of the subject. They both express and enhance the subject's confrontation with the pain of transition and transformation. They stress the inevitability of negotiations, shifts, and restructuring that lie at the heart of the process of change and how they imply both pain and exhilaration and can never avoid conflict. (Braidotti qtd. in Ng 32)

$\mathrm{Ng}$ perceives the element of transformation underlying the monstrosity within Invisible Monsters, yet he exercises a teleological perspective, as well. That is, in holding that Palahniuk's characters "embody monstrosities - the ugly freak and the terrible woman," he implies that monstrosity is the end-product of a bodily transformative process ( $\mathrm{Ng} 33)$. As reinforced by the end of Invisible Monsters, however, Palahniuk implies that monstrosity is an ongoing engagement with self and identity, seemingly endless to his protagonist Shannon, as she realizes at the end of the novel. In this way, Palahniuk maneuvers a step beyond the deconstruction to which the few critics of Invisible Monsters hold him accountable. This more radically deconstructive approach effectively allows him to re-interpret monstrosity as an intrinsic, necessary, and inescapable part of human existence.

While Slade and Ng assert the body as a locus for monstrosity in Palahniuk's Invisible Monsters, other critics locate this monstrosity in the intellect. These scholars address Palahniuk's implication of reader into the position of the Other figure as a means of questioning, devaluing, or affirming moral and societal codes/values. Their critiques contend that Palahniuk's subversive technique delves beyond literary voyeurism and into an abyss of self-exploration, 
potential guilt, anxiety, and excitement for readers; furthermore, readers might utilize their shared emotional experience with protagonist as a means to challenge or affirm their own beliefs, values, etc. Shannon, in this instance, serves as a third party through whose lens readers might examine their own instable identities. This self-reflection via the lens of a character deemed monster is made possible via the hybridity that Palahniuk attributes to his narrator. The ability of readers to empathize with a character who attempts to cope with her own anxieties regarding her ever-changing identity and conceptions of the world not only contributes to a "mental playground" effect with which readers might explore their current convictions while forming new sets of values/standards for monstrosity but also produces an almost narcissistic satisfaction for readers of monstrous texts. This narcissism is a consequence of readers' discovery that, in reading about characters that openly confess their violent, sometimes perverse, urges while maintaining a certain normality through their relatable confessions, readers simultaneously are able to explore repressed reflections of themselves. Interestingly, in the case of Palahniuk, this narcissism of reader is another implication of the reader into the role of the protagonist - while the monstrous protagonist engages in a process of self-watching, so does the reader engage in a process of introspection and self-recognition that is necessary for his/her own continued pleasure.

A theory that best explains this process is offered by Otto Rank, who originates the notion of a double/shadow/reflection, essentially an alter ego. Rank observes that this reflection, though almost universally the focal point for a number of superstitions regarding bad luck and death (as seen in the modern Gothic), seems to be "at its origin an attempt to find comfort, to ameliorate our fear of the inevitable extinction that awaits us all. The shadow is evidence of an incorporeal self, a self that exists apart from the physical body that invariably meets with death" 
(Rank 12). Furthermore, Milica Zivkovic describes the double as a figure which "pursues the subject as his second self and makes him feel as himself and the other at the same time," a factor which, when applied to Invisible Monsters, might help explain the protagonist's dependence on reader response as a means of narrative development (Zivkovic 122). While readers, at surface, might feel as though they are exploring the psychological quandaries of figures whose moral standards/internality contrast starkly with their own moral standards (i.e. "sparring" with the Other), the power which these figures exert over readers lies precisely in this ability to seem contradictory to readers.

Therefore, the value of the double, according to Zivkovic, "reside[s] in its resistance to definition, in its 'escapist' qualities, [and] in the possibility it offers to the individual to imagine himself and reproduce himself in endless ways" (122). In conjunction with the aforementioned concept of a mental playground wherein readers might reconstruct their own values and/or identity through the lenses of hybrid literary monsters, the notion of a doppelgänger- in the context of Invisible Monsters as opposed to traditional Gothic texts that pose these figures against readers- further allows readers to explore the confines of labeled existence as well as the escapist qualities of characters who attempt to break those confines within realistic settings. Critic Jesse Kavadlo maintains that Palahniuk's transgressive fiction achieves its own selfde(con)struction, "the ironic sense that the reader's cultural views by the end of the novel should be precisely the opposite of the views expressed by the narrator at the beginning" (Kavadlo qtd. in Sondergard).

Contributing to this paradox is the narrative strategy employed by Palahniuk. In "Chuck Palahniuk and the Semiotics of Personal Doom," Sidney Sondergard analyzes this strategy. She asserts that he "delivers deeply flawed characters to his readers, then immerses his charismatic 
losesr in crises that superficially seem to reinforce their shortcomings before pushing them to the point of a Kierkegaardian, change-or-die decision" (15). Prefacing her analysis of Palahniuk's use of a "semiotics of escalating anxiety" as a means of transposing readers into the emotions of the protagonist, Sondergard compares his approach to that of Antonin Artaud, whose Theatre of Cruelty exposes audience members to disconcerting subject matter. While Sondergard does not explicitly contribute this appeal to visceral impact to the Gothic tradition, she does recognize Palahniuk's unique blending of emotionality with intellectual engagement. She asserts that “reading Palahniuk's novels become the real world correlative of encountering the Nightmare Box, art-as-trap: 'What's inside the box is some fact you can't unlearn. Some new ideas you can't undiscover"' (9). Here, Sondergard is referencing Palahniuk's novel Haunted, but Palahniuk similarly imposes protagonist emotions alongside intellectual discovery on readers of Invisible Monsters, specifically pertaining to identity as well as gender identity.

Shannon McFarland, the novel's narrator, admits to employing this very technique when revealing the former identity of Seth Thomas, a roadie companion whom, until this point of revelation, readers have assumed to be a love interest of Brandy Alexander and an object of Shannon's jealousy — this jealousy has been supplemented by Shannon's slipping of estrogenic hormones into Seth's drinks. However, Shannon reveals that Seth had, during her modeling days, been her deceitful fiancé:

I couldn't tell you this until now because I want you to know how discovering this felt. In my heart. My fiancé wanted to kill me. Even when he's that much an asshole, I loved Manus. I still love Seth. A knife, it felt like a knife, and I'd discovered that despite everything that's happened, I still had an endless untapped potential for getting hurt. (Palahniuk 139) 
Not only does Palahniuk reverse the concept of situational irony in this instance, imposing on readers a shocking truth that has influenced the narrative until this point (and only at the discretion of the protagonist), but also does he cleverly manipulate direct address. Readers acquire an empathy for Shannon, a "monster" who is capable of complex human emotions and subject to the adverse consequences of a "normal" life. Palahniuk humanizes his monster, so to speak, and this is a clever strategy for renewing a shock value to future deeds committed by his now hybrid monster.

Sondergard recognizes this motif of self-denying narrative in other works of Palahniuk, and she claims it is necessary in order that his narrators achieve the illusion of authenticity and, hence, "escape succumbing to unconscious self-entrapment" that would exclude readers from emotional and intellectual participation in their narratives (10). However, a factor that she does not consider is Palahniuk's subtle deconstruction both of identity as a stable, unchanging entity (i.e. in a Platonic sense) and of the reality/appearance distinction. By providing readers with an explanation for their own response and consequent re-evaluation of the events of Shannon's narrative in light of this new information, Palahniuk simultaneously instills in readers a skepticism for the narrative, therefore subtly undermining an opposition between reality versus appearance. 
Section IV: "Some Place to be that's not on the Map": Implacable Monstrosity in Invisible Monsters

I'm not straight, and I'm not gay,' she says. 'I'm not bisexual. I want out of the labels. I don't want my whole life crammed into a single word. A story. I want to find something else, unknowable, some place to be that's not on the map. A real adventure.'-Brandy, Invisible

\section{Monsters}

In contrast with Bret Easton Ellis, whose deconstructive attitude toward literary monstrosity hinges on a universalization of the category (it lies dormant in all of us), Palahniuk denies the ontological possibility of this category. Palahniuk's more extreme remedy to the problem of a dichotomous monster/reader, object/subject relationship is an absolute skepticism pertaining truth/reality. He adopts the ontological skepticism of Cratylus, who asserts that "reality is utterly particular. Any adequate thought would have to match the flux with change of its own, so any attempt to categori[z]e reality is really like trying to cage the winds" (Blackburn). Whereas Cratylus's acknowledgement of this flux pertaining language leads him to a nihilistic abandonment of speech altogether as a means of communication, Palahniuk's transposition of this perspective into an oppressive discourse is celebratory, as mentioned previously. Rather than project sociocultural and psychological anxiety upon a physical entity, Palahniuk disables this projection within a constantly changing world — as the title of this section suggests, Palahniuk's monstrosity is physically implacable.

Palahniuk utilizes Gothic elements in Invisible Monsters as a means of advancing this notion of a physically implacable monstrosity. He both satirizes Gothic tropes and utilizes them to reveal their own contradictory natures. In this way, he achieves a self-cognizance that allows him effectively to disrupt internally a system of oppression within the Gothic genre. His employment of radical flux pertaining performance, identity, and story/myth enables him to create a region of Derridean difference in which signifier (subject) consistently replaces signified 
(object, monster, Other), and vice versa; the liberating effect of this infinite play is described by scholar David Bentley Hart:

The realm of difference is a region of freedom, chance, peril, escape, play, desire, absence, and innumerable paths of departure; it is the open horizon of becoming in its innocence, the homeland and the exile of the sign where an infinite array of signifiers [sin] excite and provoke one another into endless gaming; it is the land of unlikeness liberated at last from an ancient empire and rejoicing in itself. (53).

Palahniuk transforms the Gothic elements of watching/gazing, story/myth, and double identity in a way that, unlike his Gothic predecessors or contemporaries, allows him to unleash the monster from a territory of social confinement.

He incorporates the element of watching/self-watching in a repetitive way, both chronologically and schematically, throughout Invisible Monsters. Not only does his narrator Shannon directly assert reality as a tedious cycle of performance consisting of a necessary (and, indeed, narcissistic) self-watching and a simultaneous gazing, but also does Palahniuk subvert his protagonist, and subsequently readers, into this cycle. The effect of this protagonist and reader subversion is a denial of a stable vantage point with which to specify an Othered figure. As protagonist and readers recognize their impermanent positions in which their subjective roles infinitely are replaced by those of object, and vice versa, so, too, do they realize the liberation that this instability offers.

"It's eerie, but what's happening is the folks are staring at themselves in the monitor staring at themselves in the monitor staring at themselves in the monitor, on and on, completely trapped in a reality loop that never ends," (Palahniuk 118). Browsing the cable television, Shannon, too, is trapped in a reality loop that never ends. She cannot find a show that is 
anything but reality television — "Cristy Drank Human Blood," "Roger Lived with Dead Mother," and "Brenda Ate Her Baby" are a few of these shows that, essentially, emphasize the exact labeled existence that Shannon seeks to escape (116). Recognizing her identification with these reality TV stars, she deems herself "Bubba-Joan GotHerJawShotOff" (120). Emphasizing Shannon's implication in the unavoidable "reality loop," one channel even features Shannon during her prior modeling career. The commercial itself consists of a cyclic watching and selfwatching - "the studio audience all looks off in another direction, watching themselves watch themselves watch themselves watch Manus smile [sin] at Evie" (119). Perhaps more eerie however, is Shannon's own narcissistic gazing at her persona in the commercial, a persona who not only is watching herself on the monitor, but also is being watched by an audience. "About a hundred times I watched it, but I was only watching myself. That reality loop thing [. . .] And, jeez, I'm beautiful" she admits (120).

Andy Johnson describes this narcissism in terms of a visual cannibalism in which the eyes visually consume projected images of their own bodily manifestation. He infers that "the consumer is never supposed to be a finished product, but is seduced into endlessly looking in the mirror and attempting to adjust his/her body to reach an unattainable ideal," (Johnson 64). Though Johnson explores the implications of this visual cannibalism in the context of consumerism, inferring the infinite nature of this manipulation of image, Palahniuk also utilizes this technique to disrupt reader subjectivity (watching) as well as protagonist objectivity (being watched). Within this cycle of exchange between subject and object, there lacks the ability for a permanently Othered figure and an original form by which to measure conformity or deviation. This technique is similar to Beckett's blurring of Derrida's visor effect in Ill Seen Ill Said; 
however, rather than appeal to subject/object ambiguity, Palahniuk implements a repetitive exchange of position.

This reader implication in a cyclic watching/self-watching is extended by Palahniuk during Shannon's flashbacks to Brumbach's Department Store prior to her self-mutilation. She and her friend/fellow model Evie would stage partially truthful and partially hyperbolic tragicomedies on furniture sets in the store, entertaining audiences of department store shoppers while gaining both a narcissistic satisfaction and a sense of authenticity from their being watched: "Every afternoon, Evie and me, we'd star in our own personal unnatural habitat. The clerks would sneak off to find sex in the men's room. We'd all soak up attention in our own little matinee life [... ] I hate how I don't feel real enough unless people are watching" (69-70). As Shannon and Evie gain self-affirmation and narcissistic pleasure in recounting these episodes, so do readers, who find humor and even empathy during these emotionally heightened performances. This empathy might be a result of the agency afforded Shannon and Evie, who yearn to create and/or enhance their own stories and establish themselves as agents independent of the circumstances imposed upon them by reality. Readers experience humor not as an instinctual response to the uncomfortable or unfamiliar nature of Shannon's and Evie's performances, but rather as a direct result of the matter-of-fact attitude with which the actresses disclose disturbing information to their seemingly naïve department store audiences: "'You had a mutilated brother?' she'd say [...] 'Yeah, he was pretty mutilated, but not in a sexy way. Still, there's a happy ending,' I'd say. 'He's dead now'" (73). This emotional implication of reader mirrors the narrative implication that typifies Shannon's re-telling of her performances via flashbacks. As Shannon gazes at her previous self, a self that seeks escape from confinement to a conforming story, readers, who reflect on their empathetic relationship with Shannon during 
these performances, engage in a process of self-watching as they question their socially taboo empathy during these socially deviant performances.

In his chronological repetition of this combination of watching and self-watching, Palahniuk emphasizes this process as being necessary to identity formation as opposed to being characteristic of a particular monstrosity. Even after Shannon's self-mutilation, she expresses a desire for being watched and, through narration, for re-telling (effectively, watching) her experience as object. Reflecting on a visit to the Space Needle during which she and her fellow outcasts are dancing in an elevator to imagined technological music of the future, she acknowledges: "This guy looks at us as if we're those puppies you see behind glass in suburban mall pet stores. Like we're those puppies with yellow ooze on their eyes and buttholes [...] the future is just wasted on some people" (Palahniuk 100). While Shannon seemingly expresses dismay at the reaction of the elevator boy, readers interpret her reaction as merely another performance. Being well informed from other instances in the novel of Shannon's explicit desire for attention, readers dismiss her apparent dismay and, instead, interpret her account as yet another narcissistic and necessary reflection on her transgressive behavior. The extent of this desire is revealed by her attitude toward her self-mutilation when she comments, "sometimes being mutilated can work to your advantage. All those people now with piercings and tattoos and brandings and scarification [...] What I mean is, attention is attention" (53). Although, in this need for a watching eye, Palahniuk seems to uphold the subject/object relationship necessary for a category of monstrosity, he instead dismantles this opposition by attributing to Shannon a desire for such watching as well as a self-watching. Insomuch as she preys upon the attention as a source of self-affirmation, she resists objectification by a subject. Furthermore, reader subjectivity is dismantled as a direct consequence of implication in the reality loop of self- 
watching. The effect of this implication in performance is the advancement of Palahniuk's theme involving a lack of a stable reality in Invisible Monsters against which to judge the actions of his protagonist as real or imagined. This instability is imposed on readers in such a way that not only denies them this possibility but also affirms their own compliance with Shannon's socially transgressive behavior, therefore contributing a narcissism that further implicates them in the role of the protagonist.

Another significant technique that Palahniuk employs as a means of expressing an absolute skepticism toward the category of monstrosity is his deconstruction of story/myth. Utilized within the traditional Gothic to achieve the opposite effect, myth functions in Invisible Monsters as a denial of a definitive basis for identity construction. Shannon's companion Brandy Alexander, a source of inspiration, transformation, obsession, and loathing for Shannon, serves as an explicit proponent of this skepticism. The skeptical attitude expressed in her following words capture the narrative strategy employed by Palahniuk: "When you understand [sin] that what you're telling is just a story. It isn't happening anymore. When you realize the story you're telling is just words, when you can just crumble it up and throw your past in the trashcan, [sin] then we'll figure out who you're going to be" (61).

Not only is the episodic narrative structure of Invisible Monsters indicative of this destruction of linearity between past and present, but also is character development (or lack thereof) representative. Character development is impossible in a narrative structure that is in constant flux, "flashing" from one episode to the next in a jigsaw puzzle-like expression of events. The result of this lack of progressive development allows Palahniuk and narrator alike an expressive freedom with which they might continually become but never permanently be. Once again, readers are denied a subjectivity that otherwise might be afforded by a linear narrative 
within which to compare/contrast actions or character traits from different points in time. Brandy serves as an authorial voice for Palahniuk's attitude regarding the matter, asserting that "people are all over the world telling their one dramatic story and how their life has turned into getting over this one event. Now their lives are more about the past than their future" (117). By contrast, Palahniuk's characters are provided multiple stories that function as springboards into subsequent stories rather than function as constituent pieces of an over-arching narrative with a teleological theme throughout. If one does assert a theme, this theme is one of impermanence.

Palahniuk hyperbolizes the detachment of each story by recreating personas for his characters, a move that is reminiscent of identity doubling within the modern Gothic. What differentiates this phenomenon within Invisible Monsters, however, is the unending range of identities that are performed by the characters. In one story, Brandy assigns Shannon the role of "lost heiress to the House of St. Patience": "YYou come from escaped French aristocrat blood [. . .] You grew up in Paris, and went to a school run by nuns,"” Brandy explains (Palahniuk 107). In another story, Shannon holds her former fiancé Manus (later discovered to be Seth) hostage after he attempts to murder her during the night. Even by the end of Palahniuk's work, his protagonist expresses the need for a new story, one that is not dictated by Brandy but rather grants her agency: "What I need to learn to do for myself. To write my own story" (296).

Although, upon reflection of the events in Invisible Monsters, one might arrange them in a way that enables the rationalization of an over-arching narrative, their presentation during the reading process denies this rationalization. While reading Palahniuk's collage of narratives, readers perceive only a theme built on constant change, contradiction, and unexpected character actions. Shannon expresses her own apprehension of a constantly mutating "story": “[ . . ] a new identity. A new name. New relationships. Handicaps. It's hard to remember who I started this 
road trip being" (64). Even upon closer reading of the work, readers find it difficult to arrange the various stories into a linear narrative. Perhaps it is more enigmatic, however, that readers do not desire to rationalize Invisible Monsters, for this rationalization would detract from their emotional appreciation of the novel as well as force them to place their seemingly escapist narrator into the system of order from which she seeks confinement.

However hopeful readers might be pertaining Shannon's escape, however, the concept that allows for her rearrangement of stories, identities, and vantage point also binds her. That is, the infinite play of signifiers and signified within Shannon's realm of difference provides no escape, but rather the infinite possibility for her to create a new story. While this lack of escape might seem pessimistic on behalf of Palahniuk, he instead celebrates this territory in which social categorization is inconsistent with a lack of permanence: “There isn't any real you in you... Nothing of you is all-the-way yours [sin] Relax [...] You're safe because you're so trapped inside your culture...The world is your cradle and your trap" (Palahniuk 218-9). Insomuch as Shannon's world is one of becoming and never authentically being, the possibility of her Otherness is impossible. Just like the other "invisible monsters" in Palahniuk's work, she is merely "a product of a product of a product," and this lack of stable identity frees her from an oppressive position within society (Palahniuk 217). 


\section{Works Cited}

Asma, Stephen T. On Monsters: An Unnatural History of Our Worst Fears. New York: Oxford UP, 2009. Print.

Blackburn, Simon. “Cratylus.” The Oxford Dictionary of Philosophy. 2008. Web. 3 March 2014.

Braidotti, Rosi. "Mothers, Monsters, and Machines." Writing on the Body: Female Embodiment and Feminist Theory. Eds. Katie Conboy, Nadia Medina, and Sarah Stanbury. New York: Columbia UP, 1997. 59-79. Print.

Cixous, Hélène,“The Laugh of the Medusa.” Trans. Keith and Paula Cohen. Signs 1.4 (1976) 875-93. JSTOR. Web. 2 Mar. 2014.

Elbow, Peter. "The Uses of Binary Thinking." Journal of Advanced Composition 13.1 (1993) 5178. Web. 2 Mar. 2014.

Ellis, Bret Easton. American Psycho. New York: Vintage, 1991. Print.

Fraser, Graham. “'No More Than Ghosts Make': The Hauntology and Gothic Minimalism of Beckett's Late Work.” Gothic and Modernism: Essaying Dark Literary Modernity. Ed. John Paul Riquelme. Baltimore: Johns Hopkins UP, 2008. 168-79. Print.

Hart, David Bentley. "The Veil of the Sublime," The Beauty of the Infinite: The Aesthetics of Christian Truth. Grand Rapids: Wm. B. Eerdmans Publishing Co., 2003.

Heyler, Ruth. "Parodied to Death: The Postmodern Gothic of American Psycho." Gothic and Modernism: Essaying Dark Literary Modernity. Ed. John Paul Riquelme. Baltimore: Johns Hopkins UP, 2008. 128-46. Print.

Hume, Kathryn. Aggressive Fictions: Reading the Contemporary American Novel. Ithaca: Cornell UP, 2012. Print. 
Johnson, Andy. "Bullets and Blades: Narcissism and Violence in Invisible Monsters." Sacred and Immoral: On the Writings of Chuck Palahniuk. Ed. Jeffrey Sartain. Newcastle upon Tyne: Cambridge Scholars Publishing, 2009. 61-72. Print.

Jordan, James. Western Philosophy: From Antiquity to the Middle Ages. New York: Macmillan, 1987. Print.

LeBlanc, Elizabeth. "The Metaphorical Lesbian: Edna Pontellier in The Awakening." The Awakening. Ed. Nancy A. Walker. New York: Bedford/St. Martin's, 2000. 237-55. Print. Ng, Andrew. "Destruction and the Discourse of Deformity: Invisible Monsters and the Ethics of Atrocity.” Reading Chuck Palahniuk: American Monsters and Literary Mayhem. Eds. Cynthia Kuhn and Lance Rubin. New York: Routledge, 2009. 24-35. Print.

Palahniuk, Chuck. Invisible Monsters. New York: W.W. Norton \& Company, 1999. Print. Rank, Otto. The Double: A Psychoanalytic Study (1919). Trans. And Ed. Harry Tucker. Chapel Hill: University of North Carolina Press (1971): 1-80. Print.

Reynolds, J. “Jacques Derrida.” Internet Encyclopedia of Philosophy. 2002. Web. 3 March 2014. Riquelme, John Paul. "Dark Modernity From Mary Shelley to Samuel Beckett: Gothic History, The Gothic Tradition, and Modernism." Gothic and Modernism: Essaying Dark Literary Modernity. Ed. John Paul Riquelme. Baltimore: Johns Hopkins UP, 2008. 1-23. Print. Slade, Andrew. "On Mutilation: The Sublime Body of Chuck Palahniuk's Fiction." Reading Chuck Palahniuk: American Monsters and Literary Mayhem. Eds. Cynthia Kuhn and Lance Rubin. New York: Routledge, 2009. 62-72. Print.

Sondergard, Sidney L. "Chuck Palahniuk and the Semiotics of Personal Doom: The Novelist as Escape Artist." Reading Chuck Palahniuk: American Monsters and Literary Mayhem. Eds. Cynthia Kuhn and Lance Rubin. New York: Routledge, 2009. 9-23. Print. 
Zivkovic, Milica. “The Double as the 'Unseen' of Culture: Toward a Definition of Doppelgänger.” In Facta Universitatis—Linguistics and Literature. Ed. Nedeljko Bogdanovic. 2.7 (2000): 121-8. Print. 